\title{
PENGARUH JARAK TANAM JAGUNG MANIS (Zea mays Saccharata STURT) DAN VARIETAS KUBIS (Brassica oleracea VAR. CAPTTATA) TERHADAP HASIL JAGUNG MANIS DAN KUBIS PADA STSTEM TUMPANGSARI DI DESA CAND1KUNING, TABANAN
}

\author{
IWayan Sunarta \\ Dinas Kehutanan Propinsi Bali \\ sunarta_wayan@yahoo.com
}

\section{ABSTRACT}

The effects of Plant spacing of sweat corn \{Zea mays Saccarata Sturt) and cabbage (Brassica oleraceae var. Capitata) Variety on Yields of sweat corn and cabbage in intercropping system at the village of Candikuning, Tabanan

Diversification of plant species is needed to anticipate price fluctuation of vegetables. Intercropping system compared to monoculture can give more benefits to farmers. The arrangement of plant spacings of sweet corn and cabbage variety is expected to result in higher yields and benefits in intercropping.

The field experiment, which had the objective to study the effects of plant spacing of sweet corn and cabbage variety on yields of sweet corn and cabbage in intercropping system, had been conducted from March to July 2008. The experiment was carried out at the drayland farming area at Candikuning Village, district of Baturiti, tabanan regency, $1.200 \mathrm{~m}$ asl. In the experiment, a randomized complete block design with two factors namely plant spacing of sweet corn $(120 \mathrm{~cm} \mathrm{x} 40 \mathrm{~cm}, 180 \mathrm{~cm} \mathrm{x} 40 \mathrm{~cm}$ and $240 \mathrm{~cm} \mathrm{x} 40 \mathrm{~cm})$ and variety of cabbage (Green Nova and Summer Autumn) were used. Plant spacing of cabbage was $60 \mathrm{~cm} \times 40$ $\mathrm{cm}$. All treatments were replicated four times.

The results of experiment showed that effect of interaction between plant spacing of sweet corn and cabbage variety in intercropping was not significant on yields of sweet corn and cabbage. Individually, sweet corn plant spacing of $120 \mathrm{~cm} \times 40 \mathrm{~cm}$ gave the highest fresh weight of cob withous husk (10,91 tha"'), wich was $44.50 \%$ and $80.93 \%$ respectively higher than spacing of $! 80 \mathrm{~cm} \mathrm{x} 40 \mathrm{~cm}$ and $240 \mathrm{~cm}$ x $40 \mathrm{~cm}$. Spacing of $180 \mathrm{~cm}$ x $40 \mathrm{~cm}$ resulted in not significantly different fresh weight of cob with husk, but gave the highest fresh weight of cabbage heads (56.101 ha' ${ }^{11}$, wich was $27.36 \%$ higher tahan that at sweet corn spacing of $120 \mathrm{~cm} \mathrm{x}$ $40 \mathrm{~cm}$ and was not significantly different from that at $240 \mathrm{~cm} \mathrm{x} 40 \mathrm{~cm}$. Cabbage variety Green Nova gave the highest head $\left(56.101 \mathrm{ha}^{1}\right)$, wich was $14.48 \%$ higher than variety Summer Autumn.

Intercropping between cabbage variety Green Nova and Sweet corn at $180 \mathrm{~cm} \mathrm{x} 40 \mathrm{~cm}$ spacing resulted in the highest benefit (Rp. 20,488125 t ha' ${ }^{\prime 1}$, wich was Rp. 3,335500 higher than the average benefit of cabbage monoculture. The efficiency of land use in intercropping was higher (LER: 1.69) than in monoculture (LER: 1).

It is suggested to use cabbage variety Green Nova intercropped with sweet corn at i $80 \mathrm{~cm} \times 40 \mathrm{~cm}$ spacing. An experiment studying the effect of cabbage intercropped with sweet corn and other short season vegetables planted after harvesting cabbages is also suggested.

Keywords: Sweet corn (Zea mays Saccarata Stur-f), cabbage (Brassica oleraceae var. capitata), intercropping.

\section{PENDAHUUUAN}

Usaha tani hortikultura khususnya sayuran dataran tinggi sangat peka terhadap faktor-faktor luaryang bersifat ekstrim seperti: curah hujan dan gangguan organisme pengganggu tumbuhan (OPT) serta fluktuasi harga produk yang tajam. Kondisi demikian menyebabkan petani sayuran sering mengalami kerugian yang cukup besar sehingga tidak mempunyai cukup modal untuk usaha tani berikutnya.

Selama ini beberapa petani sayur di Kecamatan Baturiti sudah melakukan penanaman dengan sistem tumpangsari antara beberapa jenis sayuran, namun belum melakukan pengaturan jarak tanam dan pemilihan jenis serta varietas yang tepat. Dari pengamatan di lapangan ditemukan beberapa petani menanam jagung secara tumpangsari pada pertanaman sayuran dengan jarak yang terlalu renggang $(>3 \mathrm{~m})$ sehingga kurang efisien dalam penggunaan lahan. Sebaliknya jarak tanam jagung yang terlalu rapat akan menekan pertumbuhan dan hasil tan am an sayuran. Tumpangsari jagung manis dengan kubis merupakan salah satu alternatif tumpangsari 
yang dipilih, karena merupakan kombinasi antara tanaman dengan tajuk tinggi berakar dalam (jagung) dengan tajuk rendah berakar dangkaf (kubis), serta kemudahan dalam pengelolaan budidaya di kebun. Penelitian tentang tumpangsari khususnya jagung manis dengan kubis, terutama tentang pengaruh jarak tanam jagung manis dan varietas kubis (Green Nova dan Summer Autumn) pada tumpangsari belum pernah dilakukan di Desa Candikuning Kecamatan Baturiti Kabupaten Tabanan sebagai daerah sentra produksi sayuran, sehingga perlu dilakukan penelitian tentang aspek tersebut di daerah ini.

Penelitian ini bertujuan untuk mengetahui pengaruh jarak tanam jagung manis dan varietas kubis terhadap hasil jagung manis dan kubis pada sistem tumpangsari di desa Candikuning. Hasil peneiitian ini diharapkan dapat bermanfaat dan memberikan kontribusi bagi perkembangan ilmu pengetahuan dan pengelolaan usahatani sayuran di desa Candikuning dan sekitarnya untuk meningkatkan hasil dan keuntungan usaha taninya.

\section{BAHAN DAN METODE}

Percobaan dilakukan di daerah sentra produksi sayuran Dusun Kembang Merta, Desa Candikuning, Kecamatan Baturiti, Kabupaten Tabanan pada ketinggian tempat $1.200 \mathrm{~m}$ dpi.

Bahan yang digunakan pada percobaan ini adalah benih jagung manis varietas Sweet Boy, kubis varietas Green Nova dan Summer Autumn, pupuk urea, $\mathrm{KCl}$ dan pupuk kandang ayam. Alatalat yang digunakan yaitu : bajak, cangkul, penugal, meteran, timbangan, oven, pisau, hand counter, Digital Lux meter, kertas grafik, alat tulis, tali plastik, ajir, papan nama dan alat-alat lainnya yang mendukung kegiatan.

Dalam percobaan ini akan digunakan Rancangan Acak Kelompok (RAK) dengan dua faktor perlakuan yang disusun secara faktorial. Dua faktor perlakuan yang dicoba adalah jarak tanam jagung Manis Sweet Boy dan varietas kubis yang umum ditanam oleh petani. Perlakuan jarak tanam jagung manis terdiri dari empat macam yaitu : $\mathrm{J}_{0}=$ $80 \mathrm{~cm}$ x $40 \mathrm{~cm}$ (populasi 31.250 tanaman ha ${ }^{11}$ ), J, *= $120 \mathrm{~cm}$ x $40 \mathrm{~cm}$ (populasi 20.833 tanaman ha"1), J, $=180 \mathrm{~cm} \times 40 \mathrm{~cm}$ (populasi 13.888 tanaman ha"1), $\mathrm{J},=240 \mathrm{~cm} \times 40 \mathrm{~cm}$ (populasi 10.417 tanaman ha' '). Perlakuan varietas kubis yang dicoba adalah : $\mathrm{V}$, = varietas Green Nova, V, = varietas Summer Autumn. Kedua varietas kubis ditanam dengan jarak tanam $60 \mathrm{~cm} \mathrm{x} 40 \mathrm{~cm}$ (populasi 41.667 tanaman ha'). Jagung manis ditanam pada jarak tanam berbeda dengan satu tanaman lubang'.
Terdapat enam kombinasi perlakuan dan enam monokultur. Jumlah petak setiap ulangan adalah 12 petak, diulang empat kali sehingga diperlukan 48 petak percobaan. Ukuran petak percobaan 4,8 $\mathrm{m} \times 4,8 \mathrm{~m}$. Jarak antar petak $0,5 \mathrm{~m}$ dan antar ulangan $1 \mathrm{~m}$. Variabel pertumbuhan yang diukur dari tanaman sampel meliputi tanaman kubis yaitu tinggi dan diameter tajuk tanaman $(\mathrm{cm})$, jumlah daun tanaman'1 (helai), ILD, saat inisiasi krop (hst), diameter krop (cm), umur panen (hst); tanaman jagung manis yaitu tinggi tanaman $(\mathrm{cm})$, jumlah daun tanaman"1 (helai), ILD, saat tasseiing dan silking (hst), panjang dan diameter tongkol $(\mathrm{cm})$, umur panen (hst). Variabel komponen hasil (ubinan) tanaman kubis, berat segar krop (g tanaman",t ha"1), berat kering oven krop ( $\left.\mathrm{t} \mathrm{ha}^{\prime 1}\right)$, berat segar dan kering oven brangkasan (daun, batang) ( $\mathrm{ha}^{1}$ ); Tanaman jagung manis (ubinan) yaitu jumlah tongkol (buah tanaman"1 dan ha'), berat segar tongkol dengan dan tanpa kelobot ( $g$ tanaman"1 dan ha' ${ }^{1}$ ), berat segar dan kering oven brangkasan (daun, batang, klobot, janggel) ( $\mathrm{ha}^{1}$ ). Variabel lain yang diamati dalam sistem tumpangsari yaitu intensitas cahaya (lux), berat kering oven gulma ha' ${ }^{\prime}(\mathrm{t})$, nilai kesetaraan tanah (NKT), nisbah kompetitif, keuntungan dan $B / C$ ratio

Data hasil percobaan dianalisis secara statistika dengan menggunakan analisis varian (sidik ragam) sesuai dengan rancangan yang digunakan. Apabila terjadi pengaruh interaksi yang nyata terhadap variabel yang diamati (jarak tanam jagung manis dan varietas kubis) maka dilanjutkan dengan uji jarak berganda Duncan $5 \%$. Jika interaksi tersebut berpengaruh tidak nyata maka pengaruh faktor tunggal diuji dengan uji BNT 5\%. Untuk mengetahui pengaruh perlakuan tumpangsari dan perbedaannya dengan monokultur dilakukan analisis sidik ragam dalam Rancangan Acak Kelompok dengan satu faktor. Apabila perlakuan berpengaruh nyata (uji F nyata) terhadap variabel yang diamati, maka dilanjutkan dengan uji jarak berganda Duncan $5 \%$ ( Gomez dan Gomez, 1995).

\section{HASILDAN PEMBAHASAN}

Tanaman kubis dan jagung manis selama percobaan tidak mengaiarni gangguan yang serius, baik oleh serangan hama maupun penyakit tanaman. Gejala serangan ulat kubis (Plutelia xylostelia) dikendalikan dengan Proclaim 5 SG, serangan penyakit karat daun yang disebabkan oleh cendawan (Puccinia sorghi) dikendalikan dengan ftmgisida Dithane M-45 80 WP, Ridomil Gold MZ 4/64 WP. Pertumbuhan fase vegetatif jagung manis lebih Iambat dibandingkan di dataran rendah dengan 
tasseling (76,40 hst), silking ( $81,03 \mathrm{hst})$ dan umurpanen (103,23 hst)

Hasil penelitian terhadap variabel yang diamati antarajarak tanam jagung manis dan varietas kubis tidak menunjukkan pengarah interaksi yang nyata $\left(P^{\wedge} 0,05\right)$ terhadap semua variabel yang diamati. Secara tunggal varietas tasseling (76,40 hst), silking ( $81,03 \mathrm{hst})$ dan umurpanenf 103,23 hst)

Hasil penelitian terhadap variabel yang diamati antarajarak tanam jagung manis dan varietas kubis tidak menunjukkan pengaruh interaksi yang nyata (P> 0,05) terhadap semua variabel yang diamati. Secara tunggal varietas

Tabel 1. Signifikansi Pengaruh Jarak Tanam Jagung Manis (J) dan Varietas Kubis (V) serta interaksinya (JxV) dalam Tumpangsari terhadap pertumbuhan dan hasil jagung manis dan kubis, serta variabel lainnya

\begin{tabular}{|c|c|c|c|c|}
\hline \multirow{2}{*}{ No. } & \multirow{2}{*}{ Variable } & \multicolumn{3}{|c|}{ Pengaruh Perlakuan } \\
\hline & & $\mathrm{J}$ & V & $\mathrm{JxV}$ \\
\hline 1. & Jagung; manis & & & \\
\hline 1.1 & Tinggi tanaman pada umur : & & & \\
\hline & - $\quad 28$ hst & $\mathrm{TN}$ & $\mathrm{TN}$ & $\mathrm{TN}$ \\
\hline & - $\quad 42$ hst & $\mathrm{TN}$ & $\mathrm{TN}$ & $\mathrm{TN}$ \\
\hline & - $\quad 56$ hst & $\mathrm{TN}$ & $\mathrm{TN}$ & $\mathrm{TN}$ \\
\hline & - $\quad 70$ hst & TN & $\mathrm{TN}$ & $\mathrm{TN}$ \\
\hline & - 77 hst & $\mathrm{TN}$ & $\mathrm{TN}$ & $\mathrm{TN}$ \\
\hline 1.2 & Jumlah daun pada umur: & & & \\
\hline & - 28 hst & $\mathrm{TN}$ & $\mathrm{TN}$ & $\mathrm{TN}$ \\
\hline & - 42 hst & $\mathrm{TN}$ & $\mathrm{TN}$ & $\mathrm{TN}$ \\
\hline & - 56 hst & $\mathrm{TN}$ & $\mathrm{TN}$ & $\mathrm{TN}$ \\
\hline & - 70 hst & $\mathrm{TN}$ & $\mathrm{TN}$ & $\mathrm{TN}$ \\
\hline & - $\quad 77$ hst & TN & $\mathrm{TN}$ & $\mathrm{TN}$ \\
\hline 1.3 & Indeks luas daun pada umur: & & & \\
\hline & - 28 hst & $* *$ & $\mathrm{TN}$ & $\mathrm{TN}$ \\
\hline & - 42 hst & $* *$ & $\mathrm{TN}$ & $\mathrm{TN}$ \\
\hline & - 56 hst & $* *$ & $* *$ & $\mathrm{TN}$ \\
\hline F & - 70 hst & ** & $\mathrm{TN}$ & $\mathrm{TN}$ \\
\hline & - $\quad 77$ hst & $* *$ & $\mathrm{TN}$ & $\mathrm{TN}$ \\
\hline 1.4 & Saat tasseling & TN & $\mathrm{TN}$ & $\mathrm{TN}$ \\
\hline 1.5 & Saat silking & $\mathrm{TN}$ & $\mathrm{TN}$ & $\mathrm{TN}$ \\
\hline 1.6 & Umur panen & $* *$ & $\mathrm{TN}$ & $\mathrm{TN}$ \\
\hline 1.7 & Diameter tongkol & $\mathrm{TN}$ & $\mathrm{TN}$ & $\mathrm{TN}$ \\
\hline 1.8 & Panjang tongkol & $\mathbf{T N}$ & $\mathrm{TN}$ & $\mathrm{TN}$ \\
\hline 1.9 & Jumlah tongkol ph-1 & $\mathrm{TN}$ & $*$ & $\mathrm{TN}$ \\
\hline 1.10 & Jumlah tongkol ha-1 & $* *$ & $\mathrm{TN}$ & $\mathrm{TN}$ \\
\hline 1.11 & Berat segar tongkot dengan kelobot tkl-1 & $\mathbf{T N}$ & $\mathrm{TN}$ & $\mathrm{TN}$ \\
\hline 1.12 & Berat segar tongkol dengan kelobot ph-1 & $\mathrm{TN}$ & $\mathrm{TN}$ & $\mathrm{TN}$ \\
\hline 1.13 & Berat segar tongkol dengan kelobot ha-1 & $*$ & $\mathrm{TN}$ & $\mathrm{TN}$ \\
\hline 1.14 & Berat segar tongkol tanpa kelobot tkl-1 & $\mathbf{T N}$ & $\mathrm{TN}$ & $\mathrm{TN}$ \\
\hline 1.15 & Berat segar tongkol tanpa kelobot ph-1 & $\mathrm{TN}$ & $\mathrm{TN}$ & $\mathrm{TN}$ \\
\hline 1.16 & Berat segar tongkol tanpa kelobot ha-1 & ** & $\mathrm{TN}$ & $\mathrm{TN}$ \\
\hline 1.17 & Berat segar brangkasan ph-1 & $\mathrm{TN}$ & $\mathrm{TN}$ & $\mathrm{TN}$ \\
\hline 1.18 & Berat segar brangkasan ha-1 & ** & $\mathrm{TN}$ & $\mathrm{TN}$ \\
\hline 1.19 & Berat kering oven brangkasan ha-1 & *\# & $\mathrm{TN}$ & $\mathrm{TN}$ \\
\hline 2 & Kubis & & & \\
\hline 2.1 & Tinggi tanaman pada umur & & & \\
\hline
\end{tabular}




\begin{tabular}{|c|c|c|c|c|}
\hline & $\begin{array}{l}\text { - } \quad 28 \mathrm{hst} \\
\text { - } \quad 35 \mathrm{hst} \\
\text { - } \quad 42 \mathrm{hst} \\
\text { - } \quad 49 \mathrm{hst}\end{array}$ & $\begin{array}{l}\mathrm{TN} \\
\mathrm{TN} \\
\mathrm{TN} \\
\mathrm{TN}\end{array}$ & $\begin{array}{l}* * \\
\mathrm{TN} \\
* * \\
\mathrm{TN}\end{array}$ & $\begin{array}{l}\text { TN } \\
\text { TN } \\
\text { TN } \\
\text { TN }\end{array}$ \\
\hline \multirow[t]{5}{*}{2.2} & Jumlah daun pada umur: & & & \\
\hline & - $\quad 28 \mathrm{hst}$ & $\mathrm{TN}$ & TN & $\mathrm{TN}$ \\
\hline & - $\quad 35$ hst & $\mathrm{TN}$ & $\mathrm{TN}$ & $\mathrm{TN}$ \\
\hline & - $\quad 42 \mathrm{hst}$ & $\mathrm{TN}$ & $\mathrm{TN}$ & $\mathrm{TN}$ \\
\hline & - 49 hst & $\mathrm{TN}$ & $\mathrm{TN}$ & $\mathrm{TN}$ \\
\hline \multirow[t]{4}{*}{2.3} & $\begin{array}{l}\text { Indeks luas daun pada umur: } \\
\text { - } \quad 28 \mathrm{hst}\end{array}$ & $*$ & * & $\mathrm{TN}$ \\
\hline & - $\quad 35$ hst & $*$ & $*$ & $\mathrm{TN}$ \\
\hline & - $\quad 42 \mathrm{hst}$ & * & $\mathrm{TN}$ & $\mathrm{TN}$ \\
\hline & - 49 hst & $*$ & ${ }^{*}$ & $\mathrm{TN}$ \\
\hline \multirow[t]{5}{*}{2.4} & Diameter tajuk pada umur: & & & \\
\hline & - $\quad 28 \mathrm{hst}$ & $\mathrm{TN}$ & $\mathrm{TN}$ & $\mathrm{TN}$ \\
\hline & - $\quad 35$ hst & $\mathrm{TN}$ & $\mathrm{TN}$ & $\mathrm{TN}$ \\
\hline & - $\quad 42 \mathrm{hst}$ & $\mathrm{TN}$ & $\mathrm{TN}$ & $\mathrm{TN}$ \\
\hline & - 49 hst & $\mathrm{TN}$ & $\mathrm{TN}$ & $\mathrm{TN}$ \\
\hline 2.5 & Inisiasi krop & $\mathrm{TN}$ & $* *$ & $\mathrm{TN}$ \\
\hline 2.6 & Umur panen & $* *$ & $* *$ & $\mathrm{TN}$ \\
\hline 2.7 & Diameter krop & $\mathrm{TN}$ & $\mathrm{TN}$ & $\mathrm{TN}$ \\
\hline 2.8 & Berat segar krop ph-1 & $*$ & $\mathrm{TN}$ & $\mathrm{TN}$ \\
\hline 2.9 & Berat segar krop ha-1 & $* *$ & $*$ & $\mathrm{TN}$ \\
\hline 2.10 & Berat kering oven krop ph-1 & $* \#$ & $* *$ & $\mathrm{TN}$ \\
\hline 2.11 & Beratkering oven krop ha-1 & $\mathrm{TN}$ & TN & $\mathrm{TN}$ \\
\hline 2.12 & Berat segar brangkasan ph-1 & $*$ & \# & $\mathrm{TN}$ \\
\hline 2.13 & Berat segar brangkasan ha-1 & $\mathrm{TN}$ & ** & $\mathrm{TN}$ \\
\hline 2.14 & Berat kering oven brangkasan ph-1 & $\mathrm{TN}$ & ** & $\mathrm{TN}$ \\
\hline 2.15 & Berat kering oven brangkasan ha- 1 & $\mathrm{TN}$ & ** & $\mathrm{TN}$ \\
\hline
\end{tabular}

Keterangan: $\mathrm{TN}=$ tidak nyata $(\mathrm{P}>0,05) ; *=$ nyata $(\mathrm{P}<0,05) ; * *=$ sangat nyata $(\mathrm{P}<0,01)$

Pengaruh Jarak Tanam Jagung Manis dan Varietas Kubis dalam Tumpangsari dan Monokultur
Hasil penelitian terhadap variabel yang diamati antara jarak tanam jagung manis dan s varietas kubis dalam tumpangsari dan monokuiturdisajikanpadaTabel I.

Tabel 2. Signifikansi Pengaruh Jarak Tanam Jagung manis dan Varietas Kubis dalam Tumpangsari dan Monokultur terhadap pertumbuhan dan hasil jagung manis dan kubis, serta variabel Iainnya

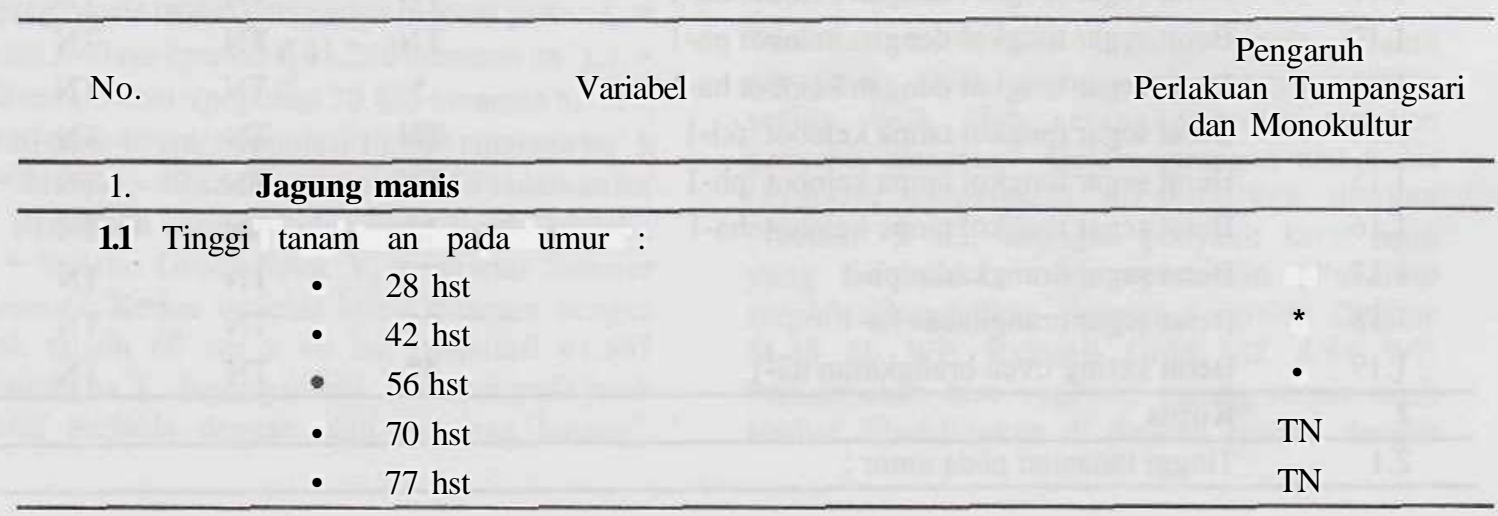




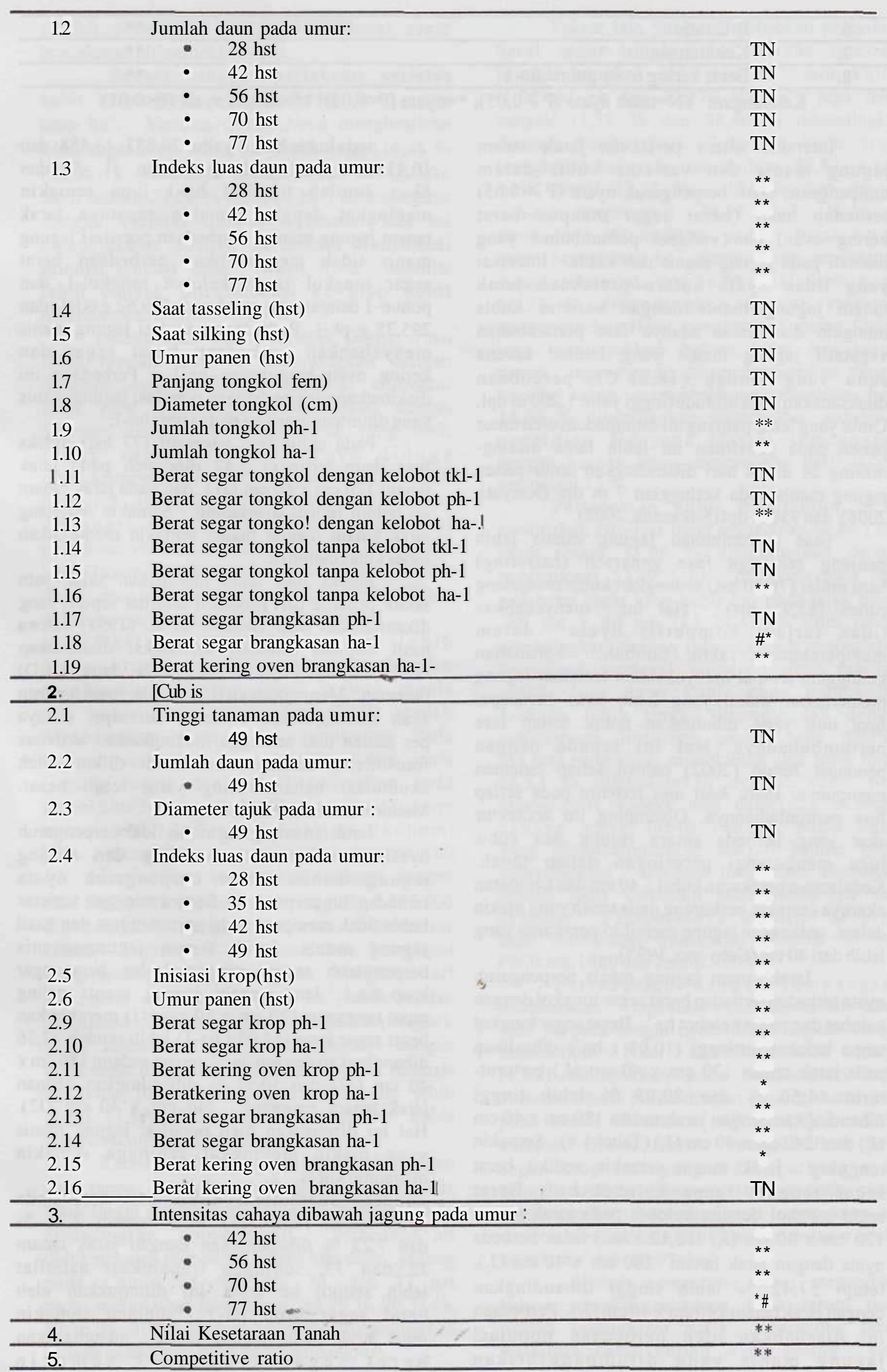




\begin{tabular}{lll}
\hline 6. & B/C ratio & $* *$ \\
\hline 7. & Keuntungan & $* *$ \\
\hline 8. & Berat kering oven gulma ha-1 & $* *$ \\
\hline
\end{tabular}

Keterangan: $\mathrm{TN}=$ tidak nyata $(\mathrm{P}>0,05) ; *=$ nyata $(\mathrm{P}<0,05) ; * *=$ sangatnyata $(\mathrm{P}<0,01)$

Interaksi antara perlakuan jarak tanam jagung manis dan varietas kubis dalam tumpangsari, tidak berpengaruh nyata $\left(\mathrm{P}^{\wedge} 0,05\right)$ terhadap hasil (berat segar maupun berat kering oven) dan variabei pertumbuhan yang diamati pada jagung manis dan kubis. Interaksi yang tidak nyata antara perlakuan jarak tanam jagung manis dengan varietas kubis mungkin disebabkan adanya fase pertumbuhan vegetatif jagung manis yang lambat karena suhu yang rendah $\left(18,88^{\prime \prime} \mathrm{C}\right)$, percobaan dilaksanakan pada altitude tinggi yaitu $1.200 \mathrm{~m}$ dpi. Umuryang lebih panjang ini ditunjukkan oieh iimur panen pada penelitian ini lebih lama masingmasing 24 dan 8 hari dibandingkan umur panen jagung manis pada ketinggian $7 \mathrm{~m}$ dpi (Karyati, 2008) dan 950 m dpi (Sukasana, 2008).

Fase pertumbuhan jagung manis lebih panjang sehingga fase generatif (tassel'mg) baru mulai (76,40 hst) sedangkan kubis menjelang panen (82,91 hst). Hal ini menyebabkan tidak terjadi kompetisi nyata dalam memperebutkan faktor tumbuh. Perubahan ketinggian tempat menyebabkan tanaman jagung memerlukan waktu yang lebih lama mencapai heat unit yang dibutuhkan untuk setiap fase pertumbuhannya. Hal ini senada dengan pendapat Jumin (2002) bahwa setiap tanaman mempunyai suatu heat unit tertentu pada setiap fase pertumbuhannya. Disamping itu arsitektur akar yang berbeda antara jagung dan kubis juga mengurangi persaingan dalam tanah. Kedalamam perakaran kubis $\pm 40 \mathrm{~cm}$ dan kerapatan akarnya semakin berkurang pada tanah yang makin daiam, sedangkan jagung memiliki perakaran yang Iebihdari40cm(Cahyono, 1995).

Jarak tanam jagung manis berpengaruh nyata terhadap terhadap berat segar tongkol dengan kelobot dan tanpa kelobot ha"1. Berat segar tongkol tanpa kelobot tertinggi (10,91 t ha") dihasilkan pada jarak tanam $120 \mathrm{~cm} \mathrm{x} 40 \mathrm{~cm}$ (J,) berturutturut $44,50 \%$ dan $80,93 \%$ lebih tinggi dibandingkan dengan jarak tanam $180 \mathrm{~cm}$ x $40 \mathrm{~cm}$ $\left(\mathrm{J}_{2}\right)$ dan $240 \mathrm{cmx} 40 \mathrm{~cm}\left(\mathrm{~J}_{1}\right)($ Tabel4.8). Semakin renggang jarak tanam semakin sedikit berat segar tongkol tanpa kelobot ha ${ }^{1}$. Berat segar tongkol dengan kelobot pada jarak tanam $120 \mathrm{~cm} \mathrm{x} 40 \mathrm{~cm}(\mathrm{~J}),\left(16,12 \mathrm{t} \mathrm{ha}^{1}\right)$ tidak berbeda nyata dengan jarak tanam $180 \mathrm{~cm} \mathrm{x} 40 \mathrm{~cm}(\mathrm{~J}$,$) ,$ tetapi 57,42 \% lebih tinggi dibandingkan dengan jarak tanam $240 \mathrm{~cm} \times 40 \mathrm{~cm}(\mathrm{~J}$,$) . Perbedaan$ ini disebabkan oleh perbedaan populasi jagung manis yang ditumpangsarikan pada kubis ha-1, yaitu $20.833 ; 13.888$; dan 10.417 ph ha-1 pada perlakuan J1, J2 dan J3. Jumlah tongkol ha-1 juga semakin meningkat dengan semakin rapatnya jarak tanam jagung manis. Perbedaan populasi jagung manis tidak menyebabkan perbedaan berat segar tongkol tanpa kelobot tongkol-i dan pohon-1 dengan rata-rata berat 179,62 gtkl-1 dan 295,75 g ph-1. Perbedaan populasi jagung manis menyebabkan perbedaan berat segar dan kering oven brangkasan ha-1. Perbedaan ini diakibatkan oleh perbedaan populasi jagung manis yang ditumpangsarikan pada kubis ha-1.

Pada akhir fase vegetatif (77 hst) indeks luas daun tertinggi 3,42 diperoleh pada jarak tanam $120 \mathrm{~cm}$ x $40 \mathrm{~cm}$ (JI) dan pada jarak tanam ini belum terjadi overlaping. Semakin renggang jarak tanam jagung manis semakin menumnkan indeks iuas daunnya.

Indeks luas daun merupakan salah satu faktor penentu dari produksi asimilat seperti yang dikemukakan oleh Gardner et al. (1991) bahwa hasil asimilat semakin meningkat diakibatkan oleh meningkatnya indeks luas daun (ILD) tanaman. Meningkatnya ILD sampai batas tertentu akan meningkatkan efisiensi intersepsi cahaya per satuan luas sehingga meningkatkan aktivitas fotosintesis tanaman, kemudian diikuti oleh akumulasi bahan kering yang lebih besar. MenurutJumin(2002).

Jarak tanam jagung manis tidak berpengaruh nyata terhadap saat tasseling dan silking jagung manis, tetapi berpengaruh nyata terhadap umur panen. Secara tunggal varietas kubis tidak mempengaruhi pertumbuhan dan hasil jagung manis. Jarak tanam jagung manis berpengaruh sangat nyata terhadap berat segar krop ha-1. Jarak tanam jagung manis paling rapat renggang $120 \mathrm{~cm} \times 40 \mathrm{~cm}(\mathrm{Jl})$ memberikan berat segar krop (44,05 t ha-1) lebih rendah 27,36 dibandingkan dengan jarak tanam sedang $180 \mathrm{~cm} \mathrm{x}$ $40 \mathrm{~cm}$ (J2) dan 30,31 \% dibandingkan dengan jarak tanam renggang $240 \mathrm{~cm} \times 40 \mathrm{~cm}$ (J2). Hal ini disebabkan oleh populasi jagung manis yang makin meningkat sehingga semakin menaungi kubis.

Indeks luas daun kubis (49 hst) pada jarak tanam rapat (JI) lebih rendah 3,31 \% dan 7,23\% dibandingkan dengan jarak tanam J2 dan J3, sehingga translokasi asimilat lebih sedikit ke krop. Ini ditunjukkan oleh berat segar krop ph-1 dimana semakin rapat jarak tanam jagung manis menghasilkan berat segar krop ph-1 semakin 
rendah sebaliknya menghasikan berat segar brangkasan $\mathrm{ph}^{\prime \prime}$ semakin tinggi.

Secara tunggal perlakuan varietas kubis berpengaruh nyata terhadap berat segar krop ha"1. Varietas Green Nova menghasiikan berat segar krop kubis hat lebih tinggi 14,48 \% (56,06 t), sebaliknya menghasiikan brangkasan lebih rendah 23,09\% (23,04 $\left.\mathrm{t} \mathrm{ha}^{\prime \prime 1}\right)$ dibandingkan dengan varietas Summer Autumn. Hal ini menunjukkan adanya perbedaan translokasi asimilat dimana pada Green Nova asimilat lebih banyak ditranslokasi ke krop kubis dibandingkan Summer Autumn.

Indeks luas daun varietas Green Nova lebih rendah 2,06\% dibandingkan dengan Summer Autumn, tetapi memiliki arsitektur tajuk yang lebih tegak dibandingkan dengan Summer Autumn. Arsitektur tajuk yang lebih tegak varietas Green Nova diduga mengkompensasi kekurangan dalam ILD. Menurut Jumin (2002) intersepsi cahaya matahari dapat dimanipulasi melalui pemilihan varietas berdaun tegak dan pengaturan jarak tanam. Gardner et al. (1991) menyatakan daun dengan orientasi vertikal lebih efisien dalam penyerapan radiasi dan fotosintesis.

Pertanaman tumpangsari lebih menguntungkan dibandingkan dengan monokultur walapun hasil jagung manis dan kubis pada tumpangsari lebih rendah dibandingkan pertanaman monokultur. Pada tumpangsari akan menghasiikan dua jenis (jagung manis dan kubis) sedangkan pada monokultur hanya menghasiikan satu jenis $G^{a}$ gung manis atau kubis). Anal is is ekonomi juga menunjukkan pertanaman tumpangsari J:V, menghasiikan keuntungan tettinggi dengan nilai Rp.20.488.125 ha"1 lebih tinggi Rp.3.335.500 dibandingkan dengan rata-rata monokultur kubis. Kombinasi ini merupakan kombinasi yang paling menguntungkan walapun dari segi berat segar krop kubis ha'" lebih rendah dari monokuiturnya maupun rata-rata tumpangsari, tetapi kekurangan ini dikompensasi dengan berat segar tongkol dengan kelobot ha ${ }^{1}$. Analisis $\mathrm{B} / \mathrm{c}$ ratio juga menunjukkan nilai yang lebih tinggi $(1,59)$ dibandingkan monokultur kubis maupun tumpangsari lainnya.

Rata-rata berat segar tongkol dengan dan tanpa kelobot ha ${ }^{1}$ pada monolkultur lebih tinggi masing-masing 58,08\% dan 6,73\% dibandingkan tumpangsari. Perbedaan ini didukung oleh perbedaan indeks luas daun jagung pada umur $28,42,56,70$, dan 77 hst pada monokultur lebih besar $30,79 \%, 26,51 \%$, $27,36 \%, 30,81 \%$ dan $21,29 \%$ dibandingkan dengan indeks luas daun pada tumpangsari.
Faktor lain yang menyebabkan perbedaan berat segar tongkol ha"1 karena rata-rata jumlah tongkol $\mathrm{ph}^{\prime 1}$ dan $\mathrm{ha}^{-1}$ monokultur (1,86 tkl ph'dan 52.179 tkl ha') juga lebih banyak $11,38 \%$ dan 88,46 \% dibandingkan dengan tumpangsari. Rata-rata berat segar brangkasan ha"1 pada monokultur 38,82 t ha"', lebih tinggi $12,23 \%$ dibandingkan dengan rata-rata tumpangsari $34,59 \mathrm{t} \mathrm{ha}^{\prime 1}$. Hal yang sama juga ditunjukkan pada berat kering ovem brangkasan ha'" dimana pada monokultur menghasiikan rata-rata $16,85 \mathrm{t} \mathrm{ha}^{\prime 1}$, lebih tinggi $16,53 \%$ dibandingkan dengan rata-rata tumpangsari. Hasil penelitian Suparsa (2004) juga menunjukkan bahwa berat biji kering panen jagung yang ditumpangasarikan dengan kacang tanah menyebabkan penurunan hasil $14,06 \%$ dibandingkan monokultur, sedangkan penelitian Udayana (2003) tumpangsari dengan kacang hijau menurunkan hasil jagung sampai60,!3\%.

Pertanaman kubis monokultur memperlihatkan rata-rata berat segar krop 69,84 t ha"1 lebih tinggi 33,08 \% dibandingkan dengan tumpangsari 52,49 $\mathrm{t}$ ha"1, demikian pula ratarata berat segar krop kubis ha"1 pada jarak tanam $180 \mathrm{~cm} \times 40 \mathrm{~cm} \quad\left(\mathrm{~J}_{;}\right) \quad 24,49 \%$ lebih rendah dibandingkan dengan rata-rata pada monokultur. Perbedaan produksi ini diakibatkan rata-rata indeks luas daun kubis pada monokultur $3,78 \%$ lebih tinggi dibandingkan dengan tumpangsari. Intensitas cahaya yang diterima (84 hst) pada kubis monokultur juga lebih tinggi $64,83 \%$ dibandingkan dengan kubis pada tumpangsari. Indeks luas daun dan intensitas cahaya yang lebih rendah pada kubis yang ditumpangsarikan dengan jagung manis menyebabkan aktivitas fotosintesa akan lebih rendah yang bermuara pada rendahnya hasil asimilat. Terbatasnya asimilat (source) akan membatasi translokasi asimilat ke sink (Wilkins, 1989dan Jumin, 2002).

Pertanaman dengan tumpangsari memberikan rata-rata nilai kesetaraan tanah 1,69 berbeda sangat nyata dibandingkan dengan monokultur. Nilai kesetaraan tanah tertinggi $(1,82)$ ditunjukkan pada tumpangsari kubis varietas Green Nova dengan jagung manis pada jarak tanam $180 \mathrm{~cm} \times 40 \mathrm{~cm}(\mathrm{~J}, \mathrm{~V}$,$) . Kubis$ varietas Green Nova menghasiikan berat segar krop ha"' yang tidak berbeda nyata dengan varietas Summer Autumn pada sistem tumpangsari. Rata-rata berat segar krop ha"1 varietas Green Nova dan Summer Autumn adalah 56,00 t ha" ${ }^{\prime \prime}$ dan 4 S,97tha"'

Nisbah competitive ratio menunjukan bahwa semakin renggang jarak tanam maka nisbah competitive ratio cenderung turun. Rata-rata berat kering oven gulma pada 